\author{
大学病院看護師における情緒的消耗感に関連する因子の検討 \\ ～母性愛信奉と性別役割分業の検討〜 \\ 高井 怜 ${ }^{1}$, 野村 恭子 ${ }^{2,3}$, 平池 春子 ${ }^{4}$, 村上 文 $^{5}$, 田辺杏由美 ${ }^{2}$,

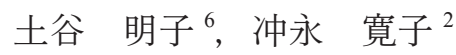 \\ '東邦大学看護学部 \\ 2 帝京大学女性医師・研究者支援センター \\ ${ }^{3}$ 秋田大学大学院医学系研究科公衆衛生学講座 \\ ${ }^{4}$ 帝京大学医学部産婦人科学講座 \\ ${ }^{5}$ 帝京大学法学部 \\ ${ }^{6}$ 帝京大学医学部附属病院看護部
}

\title{
An Investigation of Factors Associated with Emotional Exhaustion among Hospital Nurses: Adherence to "Maternal Affection" and Agreement with Stereotypical Gender Roles
}

\author{
Rei TAKAI ${ }^{1}$, Kyoko NOMURA ${ }^{2,3}$, Haruko HIRAIKE ${ }^{4}$, Aya MURAKAMI ${ }^{5}$, Ayumi TANABE², \\ Akiko TSUCHIYA ${ }^{6}$, Hiroko OKINAGA ${ }^{2}$ \\ ${ }^{1}$ Faculty of Nursing, Toho University \\ ${ }^{2}$ Teikyo Support Center for Women Physicians and Researchers \\ ${ }^{3}$ Department of Public Health, Akita University Graduate School of Medicine \\ ${ }^{4}$ Department of Obstetrics and Gynecology, Teikyo University School of Medicine \\ ${ }^{5}$ Department of Law, Faculty of Law, Teikyo University \\ ${ }^{6}$ Nursing Unit, Teikyo University Itabashi Hospital
}

\begin{abstract}
Objective: To investigate factors including adherence to "maternal affection" and stereotypical gender roles associated with emotional exhaustion among hospital nurses.

Method: In 2014, among 2,690 workers recruited for this study, 891 participated with written informed consent. Of these, we investigated 464 hospital nurses. Adherence to maternal affection and emotional exhaustion were measured using valid and reliable scales developed by Egami (2005, 12 items) and Kubo (1992, 5 items), respectively. Stereotypical gender role was measured by asking "how much do you agree with the idea that women should stay home and men should work?". Workfamily conflict was measured in terms of the discrepancy in priority in life (i.e., a work or a private life) between the participant's ideal and the real world.

Result: The majority of our participants were women $(86 \%)$, aged 39 or younger $(80 \%)$, and single (70\%). About one-quarter had workfamily conflict $(26 \%)$ and agreed with the stereotypical gender role $(\mathbf{2 8 \%})$. The mean scores of emotional exhaustion and adherence to maternal affection were 17.2 (out of 25) and 30.8 (out of 48), respectively. A stepwise multivariable model showed that being a woman $(\mathrm{p}=\mathbf{0 . 0 2 8})$, being young ( $p=0.022)$, being single $(p=0.007)$, and having workfamily conflict $(p<0.001)$ were more likely to increase emotional exhaustion after adjusting for household income. Adherence to maternal affection and stereotypical gender role were not significantly associated with emotional exhaustion.

Conclusion: This study demonstrated that adherence to "maternal affection" and stereotypical gender roles were not associated with psychological burnout. Special attention should be paid to hospital nurses who are women, young, or single, or who have workfamily conflict.
\end{abstract}

Key words: adherence to maternal affection（母性愛信奉), burnout（バーンアウト）, emotional exhaustion (情緒的消耗感), nurse (看護師) 


\section{緒言}

近年, 日本は急速な高齢化社会に直面しており，医療 の質を保つために，看護師育成と安定した供給が必要で ある。とくに育成面に打いては，看護師の教育水準を向 上させ専門性を身に付けるために，新卒看護師の離職率 はできるだけ低く抑えることが重要である。

厚生労働省の看護職員就業状況等実態調査 (1) による と, 離職理由でもっとも多いのは妊娠・出産・結婚など ライフイベントであるとされている。子供の有無は有意 に離職に結び付くことから，これまで日本看護協会が主 導となり働きながら仕事ができるワークライフバランス の推進や適正な人員配置, 柔軟な労働環境の整備など多 くの取り組みが行われてきた (2)。

看護師の離職防止のためにも「仕事と家庭の両立」が 大切とされる一方で, 先進国の中でも日本は「男は仕事, 女性は家庭」の性別役割分業意識が未だ強い社会規範を 持ち，実際には子供を持つ勤労女性の家事・育児・仕事 の過重負担は男性に比して大きいと指摘されている (3)。この「男は仕事, 女性は家庭」といら, 性別役割 分業意識は, 働く女性において母性愛信奉傾向に強く関 連することが知られている(4)。こうした古典的価值観 は仕事を続けたいと願ら女性に対して「母親といらもの は育児を優先するべき」で，家事や育児も自らの手でし なくてはとの過重負担を強いることから, 結果として精 神的疲労感が蓄積し, 職業継続のバリアンスとなってい る可能性が指摘されている(5)。

本研究の目的は, 離職に直結するといわれる精神的疲 労感（バーンアウト）に影響を与える因子について,「男 は仕事, 女性は家庭」という性別役割分業意識と母性愛 信奉とともに検討することである。

\section{対象と方法}

\section{1. 調査対象}

本研究は 2014 年 1 月から 3 月にかけて都内某医療系 私立総合大学と附属 3 病院の教職員を対象に行った環境 整備を目的としたアンケート調査の一部である。リク ルートの対象は医学・薬学・経済学・法学・文学・外国 学・教育学・理工学・医療技術学部に所属する教員 833 名及び附属の 3 病院に所属する看護師を合わせた全職員 1,857 名で，郵送法にて無記名自記式質問票の調査協力 を求めた。同意とともに調査票に回答した 939 名（回収 率 $27.9 \%$ ）のらち，職業変数に欠損值があった 48 名と

受付 2017 年 6 月 22 日，受理 2017 年 10 月 17 日

Reprint requests to: Kyoko NOMURA

Department of Public Health, Akita University Graduate School of Medicine, 1-1-1 Hondo, Akita 010-8543, Japan

TEL: +81(18)884-6087 (secretary), +81(18)884-6086 (direct),

FAX: +81(18)836-2609

E-mail: knomura@med.akita-u.ac.jp,nomurakyoko@gmail.com
本研究の目的が看護師に括ける離職防止に主眼を置いて いるため 472 名の教員を除き，464名の病院看護師を解 析対象とした。

本研究を行らにあたり，帝京大学倫理審査委員会の承 認を得て実施した（研究倫理審査番号 No. 14-109）。回 答はコード化し個人が特定されないよら配慮した。

\section{2. 調査項目}

基本属性と乙て性別（男性・女性），年齢（20 代・30 代・40 代・50 代・60 歳以上)，婚姻状況（独身・既婚）, 世帯収入 (上・中・下), 一日の平均労働時間について 尋祆た。性別に基づく「固定的性別役割分担意識」につ いては，内閣府男女共同参画局で用いられている「夫は 外で働き，妻は家庭を守るべきである」といら一文につ いて「強くそう思う」の4 点から「まったくそう思わな い」の 1 点の等間隔尺度にて尋称，「そう思う」か「そ ら思わない」の二值変数にて解析を行った（6）。

母性愛については 12 項目からなる母性愛信奉傾向尺 度（7）を用いた。一般的に母性愛は「母親が持つ，子に 対する先天的・本能的な愛情」と理解される。江上は母 性愛信奉傾向を，「社会文化的通念として存在する伝統 的性役割観に基ついた母親役割を過剩に肯定・信奉しそ れに従って育児を実施する傾向」と定義し，それを測定 する尺度として母性愛信奉傾向尺度を開発した。母性愛 信奉尺度の回答様式は「そう思う」を4，「正直そらい ら気持ちもある」を 3 ,「どちらとも言えない」を 2 「沃 ら思わない」を 1 とした 4 段階等間隔尺度からなる連続 変数で，総合点が高いほど母性愛が強いことを表す。

ワークファミリーコンフリクトに関しては，内閣府の 男女共同参画社会に関する世論調査 (6) より，生活の中 での,「仕事」,「家庭生活」, 地域活動・学習・趣味・付 き合いなどの「地域・個人の生活」の優先度について理 想の場合之現実の場合について尋水た。このうち,「家 庭生活」あるいは「地域・個人の生活」が優先なのに現 実には「仕事」を優先している場合を「ワークファミリー コンフリクトあり」と定義し，それ以外を「ワークファ ミリーコンフリクトなし」とした。

\section{3. アウトカム}

精神的疲労感（バーンアウト）については，Masalach Burnout Inventory（7）に準拠・改訂して作成した日本語 の尺度項目（8）を用いた。バーンアウトとは過度で持続 的なストレスを受けたときに威力や野心などが衰退し疲 れ果ててしまら心身の症状である。17 項目からなるこ の尺度は因子分析によって，「情緒的消耗感（emotional exhaustion)」,「脱人格化 (deparsonalization)」,「個人的 達成感（personal accomplishment）」の 3 因子に分かれる ことが明らかとなって拈り，先行研究（9）より離職に関 係するとされる「情緒的消耗感 (emotional exhaustion)」 をアウトカムとした。具体的には，「こんな仕事，もら やめたいと思うことがある。」,「一日の仕事が終わると, 
“やっと終わった”と感じることがある。」「出勤前, 職 場に出るのが嫌になって, 家にいたいと思らことがあ る。」，「仕事のために心にゆとりがなくなったと感じる ことがある。，「体も気持ちも疲れはてたと思らことが ある。」の5 項目である。それぞれを「いつもある」の 5 点から「まったくない」の 1 点まで Likert 等間隔尺度 にて回答してもらい，合計点を連続変数として扱った。

\section{4. 解析方法}

カテゴリー変数間の関連については $\chi^{2}$ 検定を行い, カテゴリー変数と連続変数の関連については $\mathrm{t}$ 検定を用 いた。アウトカムである精神的疲労感に対し, ステップ
ワイズ多変量線形回帰モデルを用い，影響する因子を検 討した。用いた共変量は性別，年齢，婚姻状況，世帯年 収, 一日平均労㗢時間 (8 時間以下 vs. 8.1 時間以上), ワー クファミリーコンフリクト, 性別役割分業意識（思らと 思わないで二值化)，母性愛（中央值で二值化）である。 分析には統計ソフトSAS version9.4を用い，有意水準は 5\%とした。

\section{結 果}

対象者である病院看護師 464 名の特徵を表 1 亿示す。 $86 \%$ が女性であり, 年齢は 20 代から 30 代が $80 \%$ を占め,

\section{表 1 対象集団の特性}

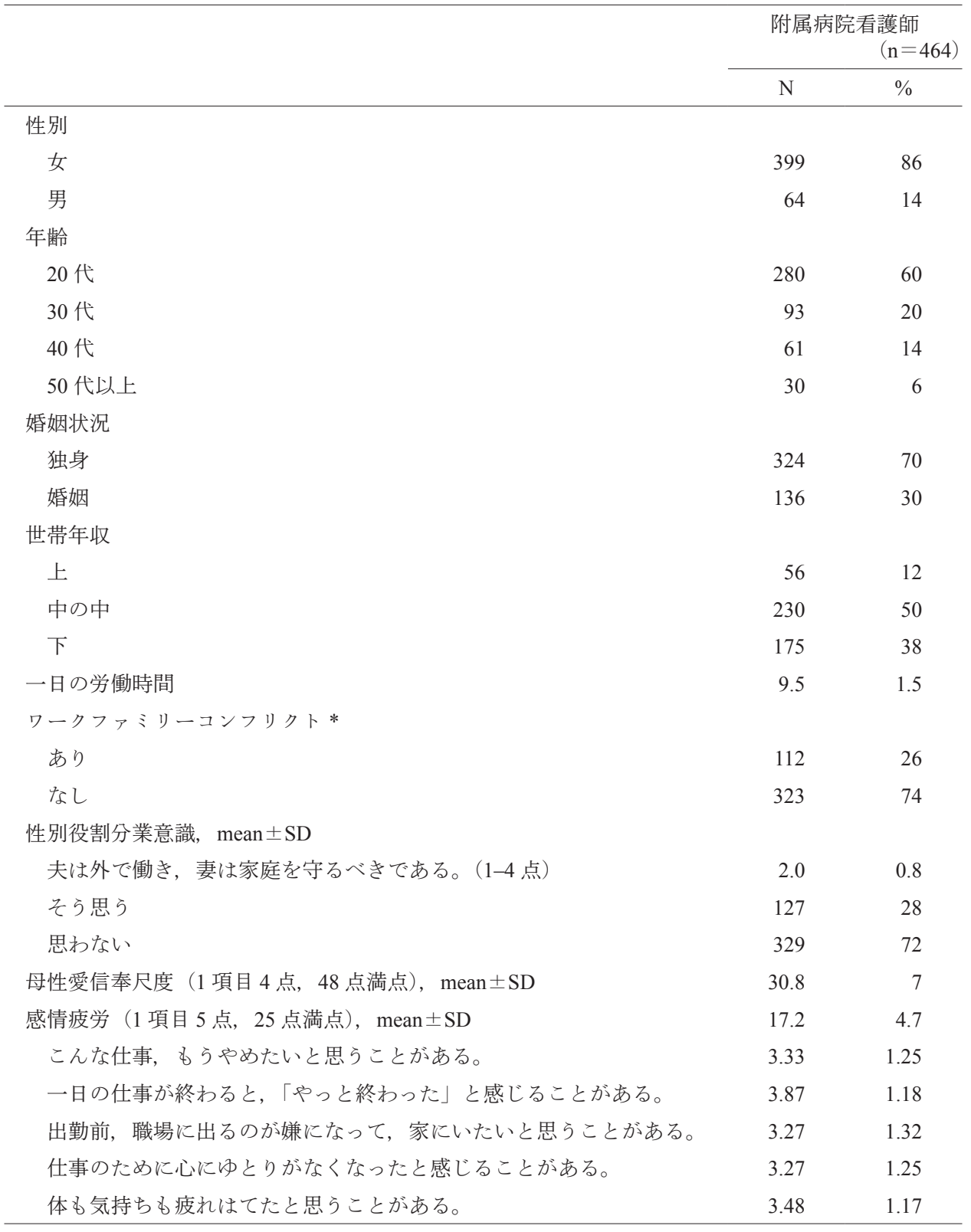

$\mathrm{N}$ が全体数に満たない場合は欠損值を表す。

*家庭・個人優先が希望なのに現実は仕事が優先になっている 


\begin{tabular}{|c|c|c|c|c|c|c|c|}
\hline \multirow[b]{3}{*}{ 母親であれば，育児に専念することが第一である。 } & \multicolumn{3}{|c|}{ 女性 } & \multicolumn{3}{|c|}{ 男性 } & \multirow{3}{*}{$\begin{array}{c}\mathrm{p} \text { 值 * } \\
0.002\end{array}$} \\
\hline & \multirow{2}{*}{$\frac{\text { 最小二乗平均 }}{2.30}$} & \multicolumn{2}{|c|}{ 95\% 信頼区間 } & \multirow{2}{*}{$\begin{array}{c}\text { 最小二乗平均 } \\
1.94\end{array}$} & \multicolumn{2}{|c|}{ 95\% 信頼区間 } & \\
\hline & & 2.21 & 2.38 & & 1.72 & 2.15 & \\
\hline $\begin{array}{l}\text { 育児は女性に向いている仕事であるから，するのが自 } \\
\text { 然である。 }\end{array}$ & 3.05 & 2.97 & 3.13 & 2.63 & 2.38 & 2.87 & 0.001 \\
\hline $\begin{array}{l}\text { わが子のためなら，自分を犠牲にすることができるの } \\
\text { が母親である。 }\end{array}$ & 2.02 & 1.95 & 2.09 & 1.73 & 1.58 & 1.89 & 0.001 \\
\hline $\begin{array}{l}\text { 子供のためなら，どんなことでもするつもりでいるの } \\
\text { が母親である。 }\end{array}$ & 2.97 & 2.88 & 3.05 & 2.50 & 2.24 & 2.76 & 0.001 \\
\hline $\begin{array}{l}\text { 子どもを産む母親だからこそ，子育ては何にもさし拈 } \\
\text { いて母親が行らべきことである。 }\end{array}$ & 2.20 & 2.12 & 2.28 & 2.03 & 1.83 & 2.23 & 0.116 \\
\hline $\begin{array}{l}\text { 子供のためなら，たいていのことは我慢できるのが母 } \\
\text { 親である。 }\end{array}$ & 2.23 & 2.15 & 2.30 & 1.94 & 1.74 & 2.13 & 0.004 \\
\hline なんといっても子どもには産みの母親が一番良い。 & 2.91 & 2.84 & 2.99 & 2.33 & 2.09 & 2.56 & $<0.001$ \\
\hline 育児に専念したいといらのが，女性の本音である。 & 3.06 & 2.97 & 3.14 & 2.80 & 2.54 & 3.06 & 0.063 \\
\hline 母親の愛情ほどに偉大で, 気高く無条件なものはない。 & 2.30 & 2.21 & 2.38 & 2.17 & 1.96 & 2.39 & 0.258 \\
\hline $\begin{array}{l}\text { 母親になることが，女性にとって存在のあかしと見な } \\
\text { される。 }\end{array}$ & 2.76 & 2.67 & 2.86 & 2.67 & 2.41 & 2.93 & 0.480 \\
\hline $\begin{array}{l}\text { 子供を産んで育てるのは，社会に対する女性のつとめ } \\
\text { である。 }\end{array}$ & 2.53 & 2.44 & 2.61 & 2.38 & 2.16 & 2.60 & 0.203 \\
\hline $\begin{array}{l}\text { 子供が小さいうちは，母親は家にいて子供のそばにい } \\
\text { てやるべきである。 }\end{array}$ & 3.00 & 2.92 & 3.08 & 2.88 & 2.66 & 3.10 & 0.266 \\
\hline
\end{tabular}

*t 検定による

$70 \%$ が独身であった。世帯年収は，50\%が「中」と回 答し，ワークファミリーユンフリクトについて $26 \%$ が 「あり」と回答していた。母性愛信奉尺度（48 点満点） と情緒的消耗感 5 項目 (25 点満点) の平均值はそれぞ れ 30.8 点と 17.2 点であった。

表 2 に男女別母性愛信奉尺度を示す。女性看護師は男 性看護師に比べ 12 項目中 6 項目で有意に点数が高かっ た。 6 項目中， 3 点以上の高得点であったものは，「育児 は女性に向いている仕事であるから，するのが自然であ る。」の 1 項目であった。

情緒的消耗感の総得点をアウトカムにした線形回帰分 析の結果を表 3 に示す。単変量で $\mathrm{p}$ 值が 0.05 未満であっ た変数は, 性別 $(p=0.002)$, 年齢 $(p<0.001)$, 婚姻状 況 $(\mathrm{p}<0.001)$, 世帯年収 $(\mathrm{p}=0.003)$, ワークファミリー コンフリクト $(\mathrm{p}<0.001)$, 性別役割分業意識 $(\mathrm{p}=0.045)$, 母性愛信奉 $(\mathrm{p}=0.035)$ であった。これらの変数を投入 したステップワイズ多変量線形回帰モデルでは, 寄与率 は 19\% で，世帯年収，性別役割分業意識，母性愛信奉 を除くすべての項目が有意であった。具体的には, 性別 で女性 $(\beta=1.36, p=0.028)$ ，年齢 $(p<0.001)$ では 50 歳以上にくらべ 20 代 $(\beta=1.73), 30$ 代 $(\beta=1.28)$ で, ワー クファミリーコンフリクトありの場合に $(\beta=3.06, \mathrm{p}<$ 0.001）情緒的消耗感の点数が高くなる傾向を認めた。 また婚姻状況では婚姻ありで点数が低くなる傾向を認め た $(\beta=-1.37, \mathrm{p}=0.007)$ 。

\section{考察}

本研究に拈いて, 大学病院看護師のバーンアウトを示 す情緒的消耗感と有意な関連を認めた因子は，女性，若 者, 婚姻状況, ワークファミリーコンフリクトであった。 一方，日本の古典的価值観である性別役割分業意識や母 性愛信奉については情緒的消耗感と有意な関連を示さな かった。

性別役割分業意識や母性愛信奉は仕事を続けたいと思 ら女性に対し, 家事や育児も自らの手でしなくてはと過 重負担を強いることになり, 精神的疲労感を蓄積させ, 就業継続することができなくなる可能性が指摘されてい る(5)。本研究の結果, 女性看護師に颃いて特に母性愛 信奉の点数が高かった項目は，「育児は女性に向いてい る仕事であるからするのが自然であるとする」, 日本で 古くから受け継がれている固定観念を強く反映してい た。若年で未婚の看護師が圧倒的に多い本研究対象集団 でこうした古い固定観念が高く認められたのは，育てら れた親や周囲，社会の考光に影響されていることが推察 される。

我が国では少子高齢化社会に直面し，国を挙げて女性 活躍推進法 (10) やニッポン一億総活躍プラン（11）など の取り組みも後押しして“働く母親”を推奨している。 それにも関わらず実際は, 多くの女性が仕事と家庭の両 立を望みながらもそれが難しく，結果として第一子出産 時に離職するものが過半数にも及んでいる (12)。この よらな女性たちにとって, 子育てイコール母親の役割と 
日衛誌 (Jpn. J. Hyg.) 第 73 巻 第 1 号 2018 年 1 月

表 3 情緒的消耗感の線形回帰モデル結果

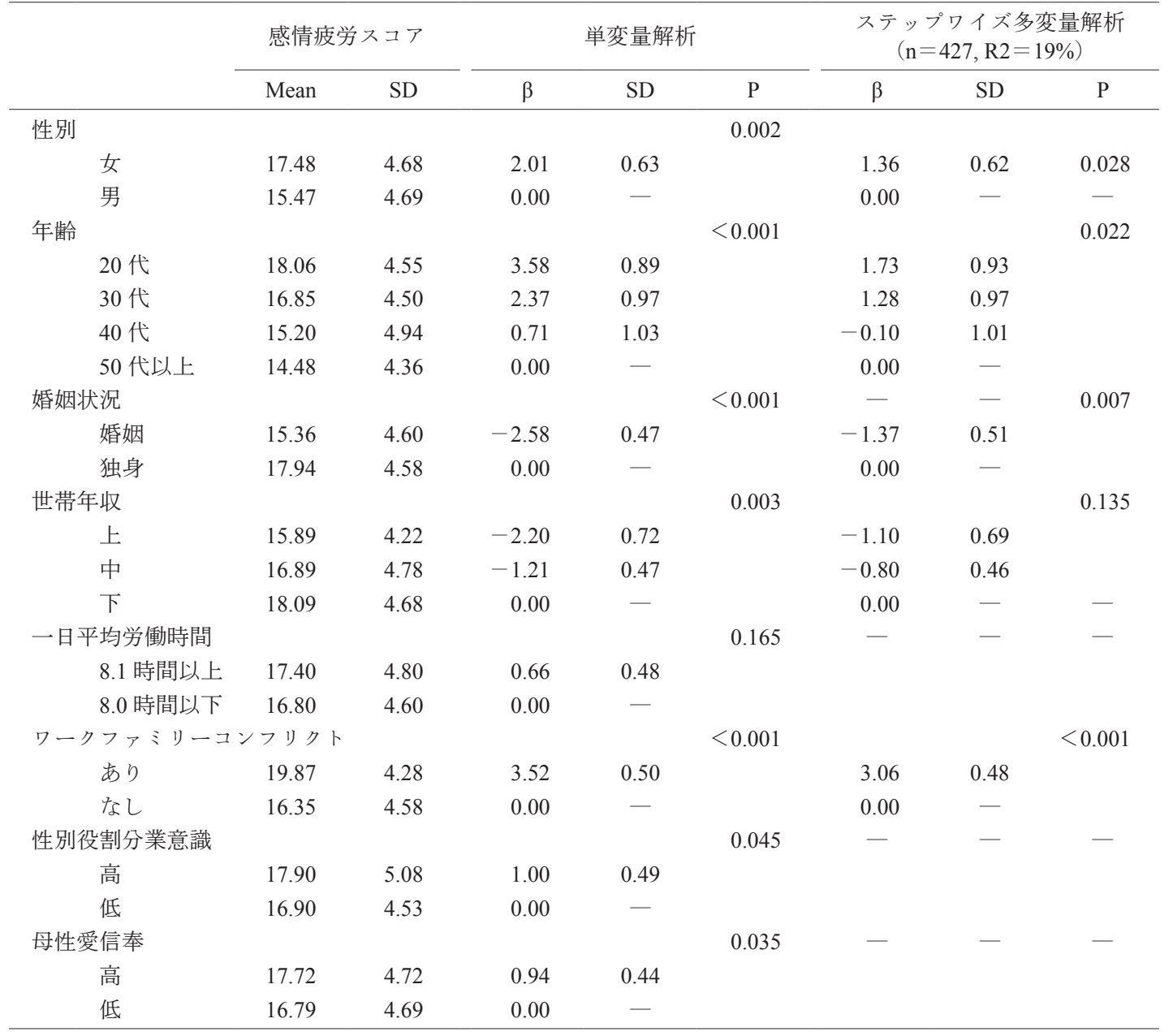

いう意識が心理的葛藤を生み，母親の精神的健康を損ね る可能性が指摘されている（13）。また母性愛が強い女 性は仕事に不満を持っているときに子育てに傾注し, 離 職に拍車をかける可能性（5）や，ガラスの天井に頭をら つと就労意欲が低下することに通じる（14）。しかしな がら本研究で, 情緒的消耗感と強い関連を示した女性, 若年，抒よびワークファミリーコンフリクトに対し，母 性愛や性別役割分業意識は単変量解析で弱い関連を認め たものの，最終的な調整モデルでは有意とはならなかっ た。この解析方法についてステップワイズ法を用いずに, 性別，年齢，婚姻状況，労働時間を投入したモデルに， 母性愛，性別役割分業，ワークファミリーコンフリクト のそれぞれの変数を独立に投入したところ，性別役割分 業で p 值が 0.069 と marginally significant であったが，母 性愛あるいはワークファミリーコンフリクトを同時に投 入すると $\mathrm{p}$ 值は有意ではなくなった。これらの結果は, 性別役割分業あるいは母性愛は看護師の離職に関係する 精神的疲労感に負の影響を及ぼすことは少ないことを示 して打り，日本の古くから伝承されたこどもを育てるた めの知恵でもある性別役割分業や母子愛に対する認識 は, 今後も大切に次世代へと受け継いでいく上で, 本研
究結果は重要である。

医療の質を担保する為に，看護師の離職防止は日本の 医療の重要課題であり，これまで職場の労働環境や適正 な人員配置, 出産後も働き続けられる保育園の確保など 職場の環境ら゙くりを中心に方策がたてられてきた（15, 16）。しかしながら本研究の結果からは，経験の浅い看 護師は精神的に消耗しやすいリスクファクターであり, 理想と現実の働き方のギャップと定義されるワークファ ミリーコンフリクトなど個人の価值観もバーンアウトに 関連する因子であることが示唆された。塚本らは就職後 早期に退職した新人看護師と就業を継続できた看護師を 比較した研究から，看護師は専門職業人としての自立性 の獲得と子育てを含めたライフイベントに直面したとき の問題解決能力を養らことが必要であると報告している (17)。看護教育の中に，このような視点を入れ，卒前に 将来遭遇するライフイベントとどのよらに仕事を両立す るか考光る機会を取り入れる等の対策が望まれる。

本研究の限界について触れる。第一に，本調査は単一 総合大学の付属 3 病院の結果であり, 本研究結果を一般 化するには限界がある。第二に，回収率が 3 割であるこ と, 本調査が女性支援ニーズ調查を母体として打り, ワー 
クライフバランスなどに関心の高いものが回答した可能 性は否定できない。また男女比率について，対象となっ た単一大学の男女比率を公表した資料はないものの，同 大学の看護学科の男女比は $1: 4 \sim 5$ (男性の割合は $17 \%$ ～20\% 程度）である。第三に，過去の先行研究に はワークファミリーコンフリクトの定義が私生活を優先 した際の現実とのギャップで定義される我々とは異なる 尺度（18）を用いてバーンアウトとの関係を検討してい るものもある。この尺度（18）は，時間・ストレス反応・ 行動に基づく仕事から家庭への葛藤と家庭から仕事への 葛藤の 6 次元で構成されている。よって, 本研究では家 庭生活を重視したいにも係わらず仕事が優先になってし まっている場合をワークファミリーコンフリクトと定義 したことついて，結果の解釈を慎重に行うことが必要で ある。最後に, 本研究は横断研究であり因果の関係につ いては言及できない。また解析に打けるモデルの説明力 (寄与率) は 19\%であり，検討できなかった因子の存在 が考えられる。本研究では一日平均労働時間のアウトカ ムに与える影響は検討できたが，先行研究（19）でバー ンアウトを惹起する要因として報告されている労働に起 因するストレスについては検討していない。以上，結果 については今後検討すべき要因も考兄られる他, 本研究 対象が大学病院に勤務する看護師に限られているため結 果の一般化には限界があるものの, 看護師の精神的疲労 感との関連要因を明らかにするための重要な示唆は得ら れて扣り，看護師の早期離職予防に寄与することが期待 される。

結論として，本研究において離職に直結するといわれ る精神的疲労感（バーンアウト）に影響を与える因子に ついて検討したところ，「男は仕事，女性は家庭」とい ら性別役割分業意識と母性愛信奉は精神的疲労感に負の 影響を与えないことが明らかとなった。精神的疲労感に 影響を与えたものは女性, 若者, 婚姻状況, ワークファ ミリーコンフリクトであり, 職業経験の比較的短い女性 が多い医療現場では，一般的な相談空口の設置の他，仕 事と私生活のバランスに対する理想と現実のギャップを 確認し, ギャップがある場合には仕事に対する付加価值 を高めていくよら職業人としてのアイデンティティーを 高めるなど介入が有用であると思われた。

\section{謝辞}

本研究を進めるに当たり帝京大学の関係者ならびに本 調査の回答者の皆様に，心から感謝申し上げます。

利益相反なし

\section{文献}

（1）厚生労働省. 看護職員就業状況等実態調査結果, 2011 .
（2）日本看護協会. 看護職のワークライフバランス.

( 3 ) Nomura K, Yamazaki Y, Gruppen LD, Horie S, Takeuchi M, Illing J. The difficulty of professional continuation among female doctors in Japan: a qualitative study of alumnae of 13 medical schools in Japan. BMJ Open (Epub 2015.3.27.) 2015;5(3):e005845. doi: 10.1136/bmjopen-2014-005845.

（4）江上園子．幼児を持つ母親の “母性愛”信奉傾向と養 育状況に打ける感情制御不全．発達心理学研究 2005; $16: 122-134$.

（5）江上園子. “母性愛”信奉傾向が幼児への感情表出に 及ぼす影響一職業要因との関連一。心理学研究 2007; 78:148-156.

（6）内閣府大臣官房政府広報室. 世論調査，2016.

( 7 ) Maslach C, Jackson SE, Leiter MP. Maslach Burnout Inventory Manual (4th Ed). Menlo Park: Mind Garden, 2016.

（８）久保真人，田尾雅夫. バーンアウトの測定. 心理学評 論 1992;35:361-367.

( 9 ) Umene-Nakano W, Kato TA, Kikuchi S, Tateno M, Fujisawa D, Hoshuyama T, Nakamura J. Nationwide survey of work environment, work-life balance and burnout among psychiatrists in Japan. PLoS One (Epub 2013.2.13) 2013; 8:e55189. doi: 10.1371/journal.pone.0055189.

（10）内閣府男女共同参画局. 女性活躍推進法，2016.

(11) http://www.gov-online.go.jp/tokusyu/ichiokusoukatsuyaku/ plan/ (2017.6.20)

（12）厚生労働省．第 1 回 21 世紀出生児縦断調査（平成 22 年出生児）の概況， 2010.

（13）岡本英雄，舩橋恵子，直井道子，松信ひろみ，江原由 美子，山田昌弘，村松泰子．母親たちのダブル・バイ ンド。目黒依子，矢澤澄子 (編)。少子化時代のジェ ンダーと母親意識. 東京 : 新曜社，2000，29-46.

(14) Nomura K, Gohchi K. Impact of gender-based career obstacles on the working status of women physicians in Japan. Soc Sci Med 2012;75(9):1612-1616.

（15）竹内節子．看護職員離職防止に向けての環境整備，安 心して働くための院内保育所 ; 看護師が働きやすい環 境づくり，24 時間 365 日型の院内保育所を開設. 看 護 2007;59:75-78.

（16）青木恵子，赤井研樹，青木喜子. 看護師免許保有者の 再就業時に打ける職場選択，選択型実験法を用いた選 好調査. 医療経済研究 2012;23(2):111-127.

（17）塚本友栄，舟島なをみ。就職後早期に退職した新人看 護師の経験に関する研究，就業を継続できた看護師の 経験との比較を通して。看護教育学研究 2008;17:2235.

（18）渡井いずみ, 錦戸典子, 村嶋幸代. ワーク・ファミリー・ コンフリクト尺度（Work-Family Conflict Scale: WFCS） 日本語版の開発と検討. 産業衛生学雑誌 2006;48:7181.

(19) Saijo Y, Yoshioka E, Kawanishi Y, Nakagi Y, Itoh T, Yoshida T. Relationships of job demand, job control, and social support on intention to leave and depressive symptoms in Japanese nurses. Ind Health 2016;54(1):32-41. doi: 10.2486/indhealth.2015-0083. 